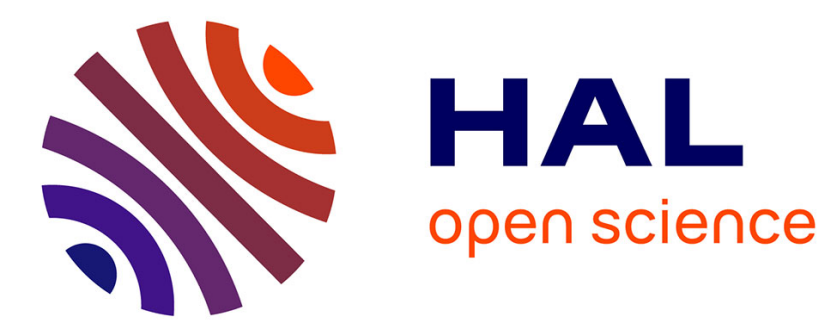

\title{
Thermal and laser-activated CVD : a comparison J.-O. Carlsson
}

\section{To cite this version:}

J.-O. Carlsson. Thermal and laser-activated CVD : a comparison. Journal de Physique IV Proceedings, 1993, 03 (C3), pp.C3-207-C3-207. 10.1051/jp4:1993327 . jpa-00251384

\section{HAL Id: jpa-00251384 https://hal.science/jpa-00251384}

Submitted on 1 Jan 1993

HAL is a multi-disciplinary open access archive for the deposit and dissemination of scientific research documents, whether they are published or not. The documents may come from teaching and research institutions in France or abroad, or from public or private research centers.
L'archive ouverte pluridisciplinaire HAL, est destinée au dépôt et à la diffusion de documents scientifiques de niveau recherche, publiés ou non, émanant des établissements d'enseignement et de recherche français ou étrangers, des laboratoires publics ou privés. 


\title{
Thermal and laser-activated CVD: a comparison
}

\author{
J.-O. CARLSSON
}

Uppsala University, Department of Chemistry, Box 531, 75121 Uppsala, Sweden

\begin{abstract}
In many CVD processes there is a complex interplay between the homogeneous reactions in the vapour and the heterogeneous growth reactions. The homogeneous reactions in the vapour can be enhanced by using hot-wall reactors or photolytic laserassited CVD with the laser beam in parallel to the substrate surface. In contrast to the use of photolysis, use of a hot wall reactor does not permit discrination between different homogeneous reactions in the vapour. This means that new reaction channels can be opened by photolysis and CVD materials different from those grown in a hotwall reactor can be produced.

Thermal laser-assisted CVD (TLCVD) differs considerably from large-area CVD. The extreme suppression of the homogeneous reactions in the vapour in TLCVD means that other precursors than those used in the large-area CVD are preferred. Similarities and differences between conventional CVD and various laser-assisted CVD processes will be discussed in connection to deposition of tungsten, aluminium, carbon, and titanium carbide.
\end{abstract}

